\title{
海外文献紹仝
}

Literature Guide

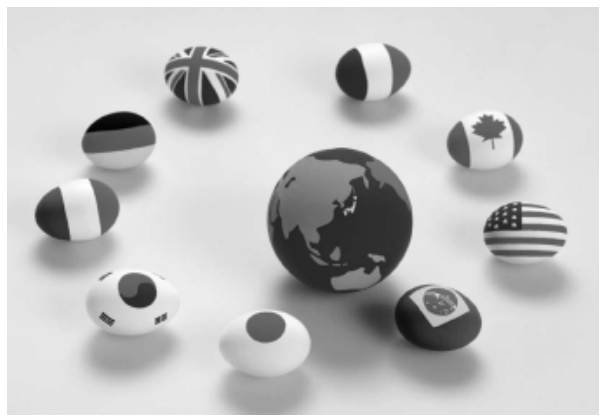

JSTが収集しているドキュメンテーション・図書館学などの雑誌から, 情報科学技術 に関する興味深い海外の文献を毎号掲載いたします。

抄録文末尾の書誌データは, 「著者名 (著者の所属機関名), 誌名 (発行国) 巻 [号] 開 始ページ・終了ページ (発行年), 整理番号」となっております。

和文文献を含む網羅的なご閲読には「科学技術文献速報」管理・システム技術編をご 覧下さい。なお，ここに紹介した文献の複写をご希望の場合は, JOISよりお申し込み いただくか, Tel.0120-004-381（複写センター）へご連絡下さい。

\section{情報政策, 知的財産権}

情報へのユニバーサルアクセス

Universal access to information

今日, デジタル化されたさまざまな情報が大量 に生み出されている。本稿では，そうした情報へ のアクセシビリティの問題について論じた。技術 の進歩により，記録可能なすべての情報に地球上 の誰でもがアクセスできる技術的可能性が生じつ つある。情報へのアクセシビリティに関して, 技 術的な障害は小さくなっている。しかし, 社会的, 法律的，および経済的な障害が残されている。ま ず第1に, この地球上には9億人の読み書きができ ない人々が居る。情報の有用性は受け手の教育に 依存しており, 道のりは遠い。第 2 に, インフラス トラクチャの問題がある。例えば現在のDVDは, 4.5GBの情報を保持でき, これは 4,500 冊の本に相 当し，安価な技術でそうした資料にアクセスでき る。最大の問題は, 経済的, 法律的問題である。情 報へのユニバーサルアクセスの費用を誰がどのよ うに賄うのかという問題がある。また, 著作権法 とその運用が, 大量に情報が生み出される今日の 状況に合わなくなっているという問題がある。ど のような解決法が考えられるのか論じた。

VARIAN Hal R. (Univ. California, Berkeley, CA, USA), Commun ACM (US) 48[10] 65-66 (2005), 05A0905201

\section{CongressへのFederal情報セキュリティ管理 法令2004（FISMA）報告 Federal Information Security Management Act (FISMA) 2004 Report to Congress.}

Federal情報セキュリティ管理法令（FISMA）は Congressによって可決され,2002年エレクトロニッ ク政府法令の一部として大統領によって署名され た。その目標は, 政府情報, 運営および資産を保護 するための総合的フレームワークの開発を含む。本 法令は, Federal agencies, NIST (the National Institute of Standards and Technology) およびOMB (the Office of Management and Budget）に対する情報システム セキュリティを強化するための特定の責務を設定 する。特に, FISMAは満足なレベルにコスト的に効 率よく情報技術非常事態を削減するための政策お よび手順を実現することを各エージェンシーのへッ ドに要求する。情報セキュリティ制御の適切性お よび効果を保証するために, FISMAはエージェン シープログラムオフィシャル, Chief Information OfficersおよびIG (Inspectors General) にエージェン シーの情報セキュリティプログラムの年次レビュー を実施し，その結果をOMBに報告することを要求 する。OMBはその監視責務で助力するために本デー タを使用し，および法令でエージェンシーコンプ ライアンスに関してCongressのために本年次報告 を準備する。報告は主として2004年10月にOMBに 
提示された政府機関およびIG報告に基づく。 (Office of Management and Budget, DC, USA), PB Rep (US) PB-2006-100961 60P (2005), 05A1002810

\section{ヒトゲノムの知的所有権地図}

Intellectual property landscape of the human genome

ヒトタンパク質をコードするヌクレオチド配列 特許の現況につき地図分析した。遺伝子配列特許 は有限数のヒト遺伝子の「土地争奪戦」に例えら れ, 過剩に広い特許は後発研究を妨げ, また高度 に細分化された特許は将来の開拓者に高コストを 課しゲノム資源の十分な活用を妨げる, との批判 がある。逆に遺伝子特許を支持する側からは, 下 流の投資や発明開示のインセンティブを提供する とされる。政策側は遺伝子特許の程度についての 経験則を欠き, 分析は事例証拠に依拠するが, そ の経験的分析は, 1)DNA配列特許の限定された(か つ定義不明確な)範囲, 2)遺伝子配列そのものをク レームした特許から単にDNA配列を開示した特許 を区別することの困難, 3) ヒトゲノムの特許と他 種の特許との区別, により妨げられている。著者 等は, US特許でクレームされているヌクレオチド 配列をヒトゲノム情報 (RefSeqやGeneデータベー ス）とBLAST相同性検索することにより, 染色体 上の特許活動の物理地図を作成した。それに従え ば,ヒト遺伝子の $20 \%$ 近くがUS特許に明確にクレー ムされ,NCBIデータベース23,688遺伝子のうち4,382 件に相当した。この特許的物理地図は一様ではな く「ホットスポット」が観察された。この地図分 析から, 特許所有者, クレーム内容, 遺伝子あた りの特許数などの興味樑い情報が得られた。

JENSEN Kyle; MURRAY Fiona (Massachusetts Inst. Technol., MA, USA), Science (US) 310 [5746] 239-240 (2005), 05A0913388

\section{第3回NTCIRワークショップにおける特許検索 の評価 \\ Evaluating patent retrieval in the third NTCIR workshop}

1990年以来の情報検索用大規模テストコレクショ ン利用の急速な拡大を反映し, さまざまな検索モ デルの有効性を調べるための広範な比較実験が実 施されてきた。しかし, 多くのコレクションは新 聞記事や技術文献を指向している。ここでは, 特
許検索向けコレクション “NTCIR-3”を生成するプ ロセスについて述べた。NTCIR-3は，2年分の日本 特許申請および特許検索専門家が作成した 31 のト ピックを含む。また，このコレクションを用いた 実験結果を報告し, 特許検索における既存検索モ デルの有効性を再調査した。既存検索モデル間の 相対的優位性は, ドキュメントジャンル(特許, 新 聞記事)に依存して大きく異なることはない。最後 に, 特許検索にかかわる課題を論じた。

IWAYAMA Makoto (Hitachi, Ltd., JPN); FUJII Atsushi (Graduate School of Library, Information and Media Studies, Univ. of Tsukuba, JPN); KANDO Noriko; MARUKAWA Yozo (National Inst. of Informatics, JPN) Inf Process Manag (GB) 42 [207-221] (2006), 05A0692829

\section{特許 : 化学関連産業における科学技術情報の ための唯一の情報源か?}

Patents: A unique source for scientific technical information in chemistry related industry?

最初の発表の情報源と最初の公表が特許文献で 行われる非特許刊行物の数についての研究を行つ た。特許情報は科学技術情報の情報源として必ず しも用いられないし, 後に特許で開示された情報 は非特許文献に必ずしも登場しない。特許で開示 された情報の独自性に関する最新の研究として, Liebesnyら（特許明細書に含まれる科学技術情報, 他の形態の文献での公表における程度 ·時間の要 素）とTerapane（情報のユニークな情報源）を挙げ た。本研究は, 特許情報が化学情報の領域で用い られない場合に, 失われているものに関する現状 データを持つために行った。CASデータベースの 特許・学術雑誌の両文献で報告されている物質サ ンプルを見ると,この情報のかなりの量が他で報 告される以前に特許に登場することが示唆される。 特許における開示が唯一の報告であるということ が, 事実と考えられる場合もある。 BREGONJE Mervyn, World Pat Inf (US) 27[4] 309-315 (2005), 05A0940478

動向の混乱一変化の時代における特許情報 Trends disrupted - patent information in an era of change

特許解析者は, 世界中の企業に公表されている 特許の数と分類を調查して研究とそのビジネス環 
境の動向を予測する。この動向予測は, 国際条約, 政府, 特許法, 特許分類システム, 企業M\&A等で 生じている変化の影響をしばしば受ける。本稿で は, 過去の特許分析による動向予測を難しくして いる特許情報環境におけるいくつかの変化につい て述べる。

SIMMONS Edlyn S. (The P\&G US Business Services Co.,OH, USA), World Pat Inf (US) 274 [292-301] (2005), 05A0940476

世界が変化する中での特許情報：

大手特許事務所の見解

Patent information in a changing world:

Perspectives from a major patent office

特許情報の分野は, 新しいツールの登場と習慣・ 考え方の変化によって流動的状態になっている。 本稿では, この状態から発生する多数の重要課題 について議論し, EPOの対応方法について述べ, 今 後の展開に関する考え方を提示する。特許は貴重 な資産としての評価が高まっているが, 特許情報, 特に文献特許情報が, 従来と同じように細部に至 るまで正確に取り扱われているか。以前に比べて, より多くの人々が特許検索を行うようになってい るが, それが特許専門家を追い出してはいないか。 IPC改革, XMLの登場, その他の発展がどのような 影響をもたらすのか。完全性, 適時性, 正確性に 重点を置くことで, 特許事務所は事態の解決に寄 与できるか。筆者は, 以前よりも一層, 老練な特 許情報専門家がその見解やニーズが, 初期データ 供給者（主に, 特許事務所）と商用データベース 供給者・受容者の両方に伝えられることを確保す ることが重要であるという結論を得た。

PILCH Wolfgang; SHALLOE Daniel (European Patent Office, AUT), World Pat Inf (US) 27 [4] 287-291 (2005), 05A0940475

知的所有権サービスにおけるプロセス指向ビ ジネスモデルによる利益を生むヨーロッパ

PATLIBセンターへの道

Route to profitable European PATLIB centres with a process orientated business model in intellectual property services

ヨーロッパにおける特許情報(PATLIB)センター は, ヨーロッパの情報サービスに対する市場状況 の変化のために, そのビジネスモデルの再編成が
必要になっている。現在の手法のみが小さい情報 サービス市場部門を網羅する結果として, PATLIB センターに対するアクセス可能な市場量の低下に なっていることを示す。さらに, 無料のWebを利 用した特許情報動向によって, PATLIBサービスに 対するコスト込み価格の達成が難しくなっている。 今後のPATLIB市場状況は, 経済的実現可能性の低 下の危険性の予測として要約される。具体的な PATLIBセンタの特徵に基づいて,ビジネスモデル の再設計について述べる。利益を生む将来の視点 を提示するために,主要顧客の顧客関係マーケティ ング (中小企業環境のビジネスの可能性)に焦点を 当てることが必要である。IPサービスセンターへ

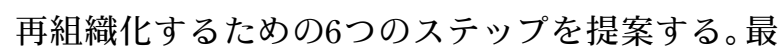
初の 2 ステップは中小企業顧客IP価值連鎖に沿った 方向性で, プロセス指向マーケティング手法であ る。次の 2 ステップは, 新しいプロセス指向を充足 する基本的ビジネスモデルである。最後は, 最高 品質の顧客サービスと再設計されたマーケティン グ活動を提供する堅固な欧州サービスネットワー クの必要性と協定である。

WURZER Alexander J.; HUNDERTMARK Stephan, World Pat Inf (US) 27 [4] 302-308 (2005), 05A0940477

\section{データベース，情報システム}

電子管理がMSDSに輝きをもたらす

Electronic management adds gloss to MSDSs

米国塗料会社(Behr Process Corp., Calif.)が導入し たMSDS管理のオンライン電子システムについて 解説した。従来の書類システムをオンライン電子 システムで置き換えることで情報へのアクセスが いっそう良くなり, 情報入手に要する費用も大幅 に節約することができるだけでなく, 従業員の安 全性を高めることができ, 連邦, 州あるいは地方 自治体から求められている化学薬品の使用量や貯 蔵に関するさまざまな規制に対する報告にも適切 に対処することができる。

BUTLER Michael (Behr Process Corp., CA, USA), Chem Process (US) 68 [9] 50-51 (2005), 05A0898417

画像を用いた単語意味あいまい性の解消

Word sense disambiguation with pictures

単語の意味のあいまいさを解消するために画像 
だけを用いる, もしくは伝統的なテキストベース の方法と組み合わせる方法を紹介した。本アプロー チは画像領域と単語の接合確率の統計モデルを用 いることにより, 最近開発された自動的に画像に 注釈を付ける方法に基づく。そのモデル自身はテ キストに関連付けられた画像データベースから学 習される。単語の意味のあいまいさ解消モデルを 使うために, 考慮中の単語の可能性のある意味に なるように, 予想される単語を制限する。単語の 予想が（可能性のある意味のような）選択を制限 された集合に制約されるとき，その信頼性はかな り高い。単語意味のあいまい性解消アルゴリズム に基づくと人工テキストの状態を増大させるが, そのままで生じる意味確率を用いた実験について 報告した。本アプローチを評価するためにSemCor コーパスから導出したあいまい性解消テキスト， およびそれと関連付けられたCorel画像データ集合 の体言部からなる新しいコーパスImCorを開発し た。それを用いた実験では視覚的な情報は単語意 味のあいまいさ解消にとても有用であることがわ かった。また, 画像データのように関連付けられ る非テキスト情報が基礎となる言語意味を助ける ことを示した。

BARNARD Kobus; JOHNSON Matthew, Artif Intell (NL) 167 [1-2] 13-30 (2005), 05A0749488

I セマンティックWebについての検索

Search on the semantic Web

ユーザとソフトウエアエージェントを支援する ために, セマンティックWeb(SWeb)の関連知識を 発見し, Swoogle検索エンジンを発見し, インデッ クスを行い, SWeb文書に符号化されたオントロ ジーと事項を解析する。SWeb検索はWebコンテン ツを電子出版に拡張したり, RDF(Resorce Description Framework)のようなSWeb言語で符号化 された知識は今までの情報とは異なること, セマ ンティックWeb文書は創成した事実, クラスや性 質定義, 論理的制約とメタデータなどを混成する ことができる。事例を挙げてこの検索の効果を説 明した。

DING Li; FININ Tim; JOSHI Anupam; PENG Yun; PAN Rong; REDDIVARI Pavan (Univ. Maryland, Baltimore, MD, USA), Computer (US) 38 [10] 62-69 (2005), 05A0893651
どうやってWorld Wide Webを検索して いるのか? 9つの検索エンジンの トランザクションログの比較

How are we searching the World Wide Web?

A comparison of nine search engine transaction logs

多くの人々にとって,Webや主要なWeb検索エン ジンはオンライン情報検索における重要なツール である。本稿では, アメリカとヨーロッパの5つの 検索エンジンに関する9つの調査に基づいて, Web 検索における特徵や変化を検証した。具体的には, セッションの長さ,質問の長さ,質問の複雑さ,Web 検索エンジン間に共通して閲覧されたコンテンッ の観点から, ユーザとWeb検索エンジン間の対話 を比較した。本調查結果から，1)ユーザは少数の 検索結果ページを閲覧していること，2)アメリカ の検索エンジン上のサーチャはヨーロッパの検索 エンジン上のサーチャよりも多くの検索操作を利 用していること，3)ブール演算の利用や閲覧され た検索結果において統計的に有意な差異が存在す ること,4)ある特定のWeb検索エンジンに関する調 査結果を他のWeb検索エンジンに必ずしも適用で きないことがわかる。Web検索エンジンの広範な 利用, 単純な質問の使用, および娭索結果ページ の閲覧減少は, Web検索企業によるアルゴリズム 的機能強化に起因するのかもしれない。また, Web 検索エンジンの開発やオンラインコンテンツの設 計にかかわる所見の意味合いを論じた。

JANSEN Bernard J. (The Pennsylvania State Univ., PA, USA); SPINK Amanda (Univ. of Pittsburgh, PA, USA), Inf Process Manag (GB) 42 [1] 248-263 (2006), 05A0692832

医学志向Webリソースの6つのヨーロッパの データベースの比較研究

A comparative study of six European databases of medically oriented Web resources

インターネットは情報へのアクセスと情報の普 及に革命をもたらし, 多様な多数のWebドキュメ ントの検索が問題となっている。本研究では, Web リソースに対する6つのヨーロッパの医学志向デー タベースを調査し, それらの特性と検索性能を比 較した。これらのデータベースは, 品質管理され た5つのサブジェクトゲートウェイと結び付いた 
データベースである。各データベースのWebリソー スの特性, 範囲, リソースを選択する手順, 記録 構造, 検索可能性, ユーザ補助の存在, などを述 べた。これらのデータベースは，1990年代に発足 し，さまざまなタイプのWebリソースを含んでい

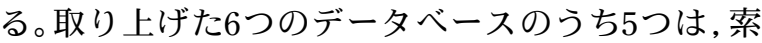
引作成に「Medical Subject Headings（MeSH)」を利 用している。これらのデータベースの検索性能を 評価するため,「心筋梗塞（myocardical infarction）」 をキーワードにして検索を実行し，検索結果を比 較した。得られた結果を踏まえ, Webリソースの 問題点と課題について考察した。

GARCIA Francisca Abad; TERUEL Aurora Gonzalez; BLASCO Lourdes Castillo (Univ. Valencia, Valencia, ESP); CALDUCH Patricia Bayo, (Doctor Peset Univ. Hospital, Valencia, ESP); DE RAMON FRIAS Rosa (La Fe Univ. Hospital, Valencia, ESP), J Med Libr Assoc (US) 93 [4] 467-479 (2005), 05A0929836

\section{$\square \square$ 図書館, 図書館員, 情報機関, 情報専門家}

\section{1世紀化学図書館}

The 21st-century chemistry library

大学の化学図書館が今後どのように変わるかを, 最近のACSの化学情報シンポジウム部会で論じら れた概要を紹介した。印刷された図書や雑誌を棚 に配置している大学の化学図書館は徐々に減少し ており, 関連機関への調査でも, 学際研究が進む 中ではデジタル媒体を通してデータベースへ接触 することが増すため, 化学図書館が独立状態で存 続する意義が薄いことや，建物のスペースを空け る意味からも, 他部門のそれらと統合の方向にあ ることを述べた。

ROVNER Sophie L., Chem Eng News (US) 83 [42] 5253 (2005), 05A0932399
デジタル図書館協力における8つの国立図書館 の事業目的：欧州図書館(TEL)プロジェクトの 事業計画について実施した研究

The business aims of eight national libraries in digital library co-operation: A study carried out for the business plan of The European Library (TEL) project

欧州の8か国 (フィンランド, ドイツ, イタリア, オランダ, ポルトガル, スロベニア, スイス, イ ギリス）の国立図書館が協力するデジタル図書館 プロジェクト計画の実施過程と結果の概要を述べ た。プロジェクトは2001年1月に開始され 2004 年1 月に完了した。参加国の現在までのデジタル製品 およびサービス, 事業要求の分析, コンサルテー ション結果のまとめなどを述べた。

COLLIER Mel (Northumbria Univ., GBR), J Doc (GB) 61 [5] 602-622 (2005), 05A0910643

Webプラットフォーム間の相互作用に関する 俯瞰（ふかん）的考察 A bird's eye view of cross-platform Web interaction

公共図書館にWebとオンライン・カタログの $2 つ$ の情報システムをマージする時の相互作用のダイ ナミクスを検討した。それは, WebとWebオンライ ン・カタログの公共図書館利用者の行動を収集, 記述, 分類することである。特に, 次の $2 \supset$ 問題 に関するWebとWeb図書館カタログの利用者相互 作用を調べた。(1)オンライン・カタログのWeb検 索への影響, (2)Webのオンライン・カタログ検索 への影響。31人の対象者の検索ログから利用者の 行動を観察し,インタビューを行った。その結果， 従来のオンライン・カタログの利用に慣れている 人は, 利用経験のない人よりもWebツールの利用 が容易であり, Web利用経験者は, Web検索と同様 なオンライン・カタログ検索を期待していた。し かし，1つのシステムの単純なミススペリングが, 他のシステムに複製されたような場合を想定すれ ば分かるように, 複数の検索環境では, あまりに 密接なシステム間の関係性は利用者の大きな混乱 を招くことを示した。

SLONE Debra J. (Clark Atlanta Univ., GA, USA), J Doc (GB) 61 [5] 657-669 (2005), 05A0910646 


\section{情報検索，情報提供・利用}

学術研究と情報実践 : 領域分析アプローチ

Scholarly research and information practices: A domain analytic approach

本稿では, 科学技術研究分野の理論を紹介し, 学術コミュニティにおける情報のニーズ, 探索, 検索，および利用を論じた。特に, Whitleyの“相 互依存性”および “タスク不確実性”に関する理 論が知的分野の情報実践における類似性と差異の 理解に関する説明フレームワークとして利用でき ることを示し,情報科学における領域分析アプロー チに寄与した。物理科学, 応用科学, 社会科学, 芸 術および人文科学を横断する3つの専門学術コミュ ニティに関する定量的事例研究に基づいて,Whitley の理論を情報通信技術分野に拡張した。ここでは, 非形式的および形式的科学コミュニケーションの 伝統と知的分野を横断したデジタル成果を具体化 する方法の間の相互関係を理解し, 情報実践に向 けた総体論的アプローチを採用した。高程度の “相 互依存性”と低程度の “タスク不確実性”を伴う 分野のコミュニティは, コミュニケーションチャ ネルの調整や統制に熟達しており, 分野べースの デジタル資源を直ちに共同作成できる。一方, 正 反対の文化形態で特徵付けられる,すなわち低程 度の “相互依存性” と高程度の “タスク依存性” を 伴う分野のコミュニティは, コミュニケーション チャネルの命令統制に成功しているとは言えず, 分野ベースのデジタル資源の共同作成やそれらを 知識的および社会的構造に統合することにも関心 が低い。これらの所見は, 文化感応型開発や, 電 子図書館およびWebベース主題ポータルなどの学 術デジタル資源の準備との密接なかかわりを持つ。 FRY J. (NERDI, NIWI-KNAW, NL), Inf Process Manag (GB) 42 [1] 299-316 (2006), 05A0692835

\section{引用ネットワークにおける雑誌の相対的 影響力の評価}

Assessing the relative influence of journals in a citation network

学術雑誌は知識の創造と普及の場になっており, 引用により関連する雑誌の引用ネットワークが形 成される。本稿では, 引用ネットワークにおける 雑誌の相対的影響力を調べた。雑誌のランク付け
を行う従来の引用調査と異なり, 引用ネットワー クにおいて知識源となる重要雑誌および知識の保 管庫となる雑誌を同定することで, 雑誌の相対的 影響力を評価した。最近のCACM (Communications of the ACM）誌の記事で引用された27誌を対象に 引用データを収集した。1998〜2002年の間に引用 されたすべての記事のリストを引用索引から得た。 そして, 引用ネットワークにおける 27 誌の雑誌の 相対的影響力を調べた。知識源としての影響力を 計算しその順位を調べ, 併せて保管庫としての影 響力を示した。さらに, 引用の流れのデータに基 づき, Ward法による凝縮型階層的クラスタリング を行い, 階層ツリーを得た。こうした雑誌のグルー ピングから,いくつかの興味深い知見が得られた。 NERUR Sridhar; SIKORA Riyaz; MANGALARAJ George (Univ. Texas at Arlington, TX, USA); BALIJEPALLY VenuGopal, (Prairie View A \& M Univ., TX, USA), Commun ACM (US) 48 [11] 71-74 (2005), 05A0966235

\section{医学文献の増加と分散化 : 根拠に基づく 医療との関係 \\ Growth and decentralization of the medical literature: Implications for evidence-based medicine}

根拠に基づく医療はピアレビュー文献に依存し ているが, MEDLINEには医学文献の膨大な索引が 含まれている。本論文では, 医学文献の増加とそ の特性について調査した。2003年のMEDLINEを利 用し，1978年から2001年にかけて公表されたすべ ての雑誌記事のデータを調査した。1978〜1985年, 1986〜1993年, 1994〜2001年の3つの時期に分けて 調査データを示した。3つの時期における年間の記 事数とページ数, 内容 (ヒトの患者と無作為化対 照試験), 著者数, 研究資金源, などの推移を示し

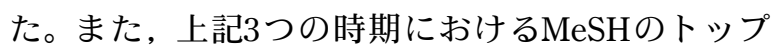
5 の主題分野の変遷（へんせん）を示した。こうし た調査結果を踏まえ, 医学研究や医療慣行におけ る変化や, 情報の増加に伴う資金源や著者の分散 化パターンなどについて論じ, 根拠に基づく医療 との関係について考察した。

DRUSS Benjamin G. (Emory Univ., GA, USA); MARCUS Steven C. (Univ. Pennsylvania, PA, USA), J Med Libr Assoc (US) 93 [4] (2005), 05A0929841 
InfVis 多次元化学データセットのプラット ホームに依存しない可視データマイニング InfVis - Platform-Independent Visual Data Mining of Multidimensional Chemical Data Sets

薬物開発における膨大なデータベース群からの 抽出および迅速で徹底したデータマイニングのた めのツールが望まれている。本報告では化学者の ための多変量化学データセットのプラットホーム に依存しない可視化, 探索, 解析およびデータマ イニングの3D可視化ツールとしてInfVisを開発し た。動的質問デバイスなどのインタラクティブお よびダイナミックツールによりデータセットの実 時間双方向処理を用いる相関およびパターンの同 定が可能である。JAVAおよびJAVA3Dに搭載し, 広 範囲のプラットホームおよびオペレーテイングシ ステムに適応することを確かめた, Webべースの インターフェイスにアプレットとして搭載するこ とも可能である。アルドール縮合反応について反 応最適化および反応計画への利用例を示した。 OELLIEN Frank; IHLENFELDT Wolf-Dietrich; GASTEIGER Johann (Univ. Erlangen-Nuremberg, Erlangen, DEU), J Chem Inf Model (US) 45 [5] 14561467 (2005), 05A0906496

Web検索セッション中におけるマルチ タスキング

Multitasking during Web search sessions

Web検索システムあるいは情報検索システムと のユーザの単一セッションは, 単一あるいは複数
のトピックの探索，およびタスク間やマルチタス ク情報行動の切り替えから構成される。多くのWeb

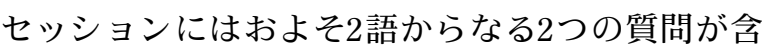
まれる。しかし，3つ以上の質問から構成されるも のもある。ここでは, 2つの調査からの所見を示し た。そのひとつは, “AltaVista” Web検索エンジン 上の2質問検索に関する調査であり，もうひとつ は, 同エンジン上の3つ以上の質問検索に関する調 査である。特に, これらの “AltaVista” Webセッショ ンの 2 セット間のマルチタスキング探索と情報タス ク切替の程度を調べた。2002年の “AltaVista”トラ ンザクションログから2質問および3質問以上のセッ ションのサンプルを取り出し, 定量的に分析した。 セッション時間は 1 分以下から数時間に及ぶ。所見 には, 1) 2質問セッションの $81 \%$ は複数のトピック を含むこと，2) 3以上質問セッションの91.3\%は複 数のトピックを含むこと，3) マルチタスキング検 索セッションにはトピックの広範な多様性がある こと,4) 3以上質問セッションには, 時々, 頻繁な トピック変更があること, が含まれる。マルチタ スキングはWeb探索における成長要素になる。ま た，文脈的にマルチタスキングフレームワークに 含まれる対話型情報検索向けのアプローチを提案 した。さらに, Webの設計や将来研究にかかわる 上記所見の意味合いを論じた。

SPINK Amanda; PARK Minsoo (Univ. of Pittsburgh, PA, USA); JANSEN Bernard J. (The Pennsylvania State Univ., PA, USA); PEDERSEN Jan (Yahoo Web Search Div., CA, USA), Inf Process Manag (GB) 42 [1] 264-275 (2006), 05A0692833 